Natalia Pochroń

\title{
PRAWA CZLOWIEKA, PRAWA NARODÓW - ZA WSZELKĄ CENĘ CZY POMIMO WSZYSTKO?
}

Niewinną, zasmuconą twarzyczkę pięcioletniej Sary pierwszy raz od dłuższego czasu rozświetla uśmiech. Na dnie ostrożnie wysuniętej szuflady znalazła pluszowego misia. Takiego, bez jakiego dawniej nie wyobrażała sobie zasnąć. Dziś już swojego nie ma. Został zbombardowany wraz z domem, z którego nie tak dawno uciekła. To pewnie dlatego co noc nawiedzają ją koszmary, o których mówi z lękiem, skrywanym ze starannością, na jaką tylko stać kilkuletnie dziecko: „Boję się snów. Śni mi się, że chodzę po domu i nagle dokoła mnie stają snajperzy.

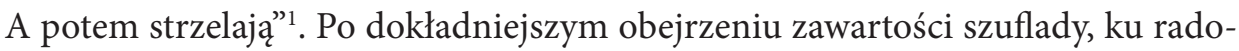
ści dziewczynki okazuje się, że zabawek jest więcej. Pragnie zabrać je wszystkie, ale nie pomieści ich w małych rączkach. Prosi więc o pomoc starszą siostrę, ale ta nie może tego zrobić - trzyma karabin. Sara pragnie zachować zdobycze, ale siostra jej nie pozwala: „Nie wolno zabierać rzeczy z cudzych domów”. Po wielu upomnieniach ze łzami w oczach wraca do domu. Smutna udaje się do pokoju z zamiarem oddania swoich żalów poduszce - najwierniejszemu powiernikowi ludzkich łez. Wpierw musi jednak posprzątać ukryte w pościeli odłamki szkła, pochodzące $z$ wybitego okna. To dzieło zniszczenia najpewniej jest wynikiem eksplozji bomby, która skruszyła szkło podobnie, jak rozbiła na drobne części dziecięcy świat, a wraz z nim marzenia o spokojnym, błogim dzieciństwie. Marzenia dziecka, które nie pragnęło niczego więcej poza poczuciem bezpieczeństwa i pewnością, że kiedy świt rozproszy mroki nocy, obudzi się tak jak zasnęło - w objęciach ulubionego misia.

Tak jest dzisiaj w ogarniętej wojenną zawieruchą Syrii. W rozerwanej ideologicznie Ukrainie. Tak było w targanej wojną domową Bośni i Hercegowinie. Rwandzie, Libii, Egipcie, Pakistanie, Strefie Gazy i wszystkich krajach pogrążonych w konflikcie zbrojnym. Konflikcie, którego skutki najdotkliwiej odczuwają cy-

\footnotetext{
1 Syria. Dzieci wojny, reż. M. Mettelsiefen, Wielka Brytania 2014.
} 
wile, a wśród nich niewinne, bezbronne dzieci. Obok działań militarnych oraz ich tragicznych konsekwencji wszystkie wojny, niezależenie od skali, łączy jeden fakt - pogwałcenie fundamentalnych praw, przysługujących nie tylko narodom, ale i tworzącym ich główną tkankę ludziom. Historia XX wieku, będąca w dużej mierze historią upodlenia człowieka, pokazuje dobitnie, że wszędzie tam, gdzie ludność pozbawiano godności, tam niemal automatycznie powstawało zarzewie konfliktu. Czy to na łonie najbardziej podstawowej komórki społecznej, jaką jest rodzina, czy też eskalującego poza nią, na całe społeczeństwo. Zawsze też pociągał on za sobą ofiary, które musiały za niego zapłacić najwyższą cenę - swojego życia. Dlatego też przestrzeganie praw człowieka oraz tworzących wspólnotę światową narodów może jako jedyne zagwarantować globalną harmonię, która swój wyraz znajdzie w harmonii międzyludzkiej.

Tematyka praw przysługujących człowiekowi i narodom zajmuje szczególne miejsce w nauczaniu Świętego Jana Pawła II. Skąd u papieża Polaka tak pogłębione refleksje na ten temat? Niewątpliwie był on człowiekiem przełomu czasów. Jako młody chłopak żył w okresie totalitaryzmów, które powołując się na odmienne ideologie, ograniczyły prawa narodów do minimum. Te bolesne doświadczenia głęboko wyryły się w jego sercu i spowodowały, że wyciągnął z nich ponadczasową lekcję. Jej założeniami nie tylko kierował się do ostatnich chwil życia, ale i postanowił podzielić się z całym światem, co stało się możliwe po objęciu steru Stolicy Piotrowej. Jako papież pochodzący zza „żelaznej kurtyny”, z „dalekiego kraju” naznaczonego bolesnym bagażem doświadczeń, kraju, który na własnej skórze przekonał się, co znaczy być pozbawionym wszystkich praw, łącznie z najważniejszym - prawem do istnienia, zyskał ku temu szczególną sposobność. Dlatego pomny bolesnej historii własnej ojczyzny, mając przed oczyma tragedię, jaką pociągnęly za sobą nieludzkie totalitaryzmy oraz perspektywę poważnych konfliktów, jaką roztoczyły napięte stosunki świata okresu zimnej wojny, ze szczególną determinacją i zaangażowaniem domagał się prawa do wolności, suwerenności i poszanowania tożsamości kulturowej - nie tylko dla własnych rodaków, ale i dla pozostałych, ujarzmionych komunizmem narodów. Tym samym przyczynił się nie tylko do odnowy oblicza polskiej ziemi, ale także do zmiany funkcjonowania państw Europy Środkowo-Wschodniej.

Oczywiste jest, iż niczym byłyby prawa narodów, gdyby nie były osadzone w pierwotnych i podstawowych względem nich prawach człowieka. Tę naturalną zależność podkreślał Jan Paweł II w słowach homilii skierowanej do rodaków na placu Zwycięstwa: 
[...] nie sposób zrozumieć człowieka inaczej jak w tej wspólnocie, którą jest jego naród. Wiadomo, że nie jest to wspólnota jedyna. Jest to jednakże wspólnota szczególna, najbliżej chyba związana z rodziną, najważniejsza dla dziejów duchowych człowieka².

W podobnym tonie ojciec święty wypowiadał się także w liście Gratissimam sane, w którym wyraził przekonanie, iż więź organiczna, jaka łączy człowieka z zamieszkiwanym przezeń narodem, zasadza się na tym, iż „rodzice w pewnym znaczeniu rodzą swe dzieci także dla narodu, ażeby były jego członkami, aby były współuczestnikami dziedzictwa historycznego i kulturowego, jakim ten naród dysponuje"', a idąc dalej - stanowiły nierozerwalną część jego zbiorowej tożsamości. Podobnych sformułowań można by szukać bez końca. Z wszystkich wypływa przekonanie Jana Pawła II, iż owa współzależność, poza pozytywnym aspektem, implikuje także pewne zagrożenie - iż naruszanie praw człowieka idzie w parze z pogwałceniem praw narodów. Czy rzeczywiście losy pojedynczego człowieka są tak powiązane z zamieszkiwaną przezeń społecznością, że mogą mieć wpływ nie tylko na nią, ale i na sprawy światowe? Czy w obliczu transformacji, jaka dokonała się od czasów zimnej wojny, sumienie człowieka - sumienie świata, miało prawo pozostać nienaruszone?

\section{Sara pragnie żyć}

Kiedy spadła tu bomba - umarłam. Kiedy w tamten dom trafiła rakieta - znowu umarłam. Umarłam, ale ożyłam. Pewnego razu ktoś wystrzelił rakietę, która wbiła się w mur, wybuchła i wszędzie latały odłamki. Proszę pana, ile to jeszcze będzie trwało? Jak długo? ${ }^{4}$

Sara pyta o to dziennikarza, spoglądając nań dużymi, czarnymi oczyma, w których próżno doszukiwać się jakiegoś wyrazu czy emocji. Kiedy sama byłam dzieckiem, podobne obrazy wywoływały we mnie przerażenie. Sara w ciągu swojego życia zdążyła oswoić się ze strachem. Jej tato jest w końcu rebeliantem. Abu Ali jest dowódcą odcinka frontu, przy którym aktualnie mieszka, i dowodzi batalionem walczącym z reżimem Baszara al-Assada. Abu Ali postanowił, że zrobi wszystko, by syryjska rewolucja rozszerzyła się na cały świat. Sara nie może się więc bać. Dla dobra rewolucji.

2 Jan Paweł II, Homilia w czasie Mszy Św. odprawionej na placu Zwycięstwa, [w:] A. Sujka, Gaude Mater Polonia, Kraków 2010, n. 3b, s. 55.

3 Jan Paweł II, List do rodzin Gratissimam sane, n. 17, Fundacja Opoka, http://www.opoka. org.pl/biblioteka/W/WP/jan_pawel_ii/listy/gratissimam.html (10.09.2017).

${ }^{4}$ Syria. Dzieci wojny, dz. cyt. 
Nie przypadkiem Jan Paweł II już w pierwszych dniach swojego pontyfikatu określił się mianem „papieża życia i odpowiedzialnego rodzicielstwa”. W tym krótkim sformułowaniu zawarł priorytety swojej posługi na Stolicy Piotrowej, czemu dał wyraz w każdym niemal wymiarze swojego pasterskiego przewodnictwa wspólnocie Kościoła. Przez cały jego okres z niegasnącym zapałem nauczał, iż „bronić życia i umacniać je, czcić je i kochać - oto zadanie, które Bóg powierza każdemu człowiekowi”' . Co warte zauważenia, Jan Paweł II nie czynił w tej kwestii rozróżnienia na ludzi wierzących oraz tych, którzy nie rozpoznali Bożego Objawienia w swoim życiu. Jak bowiem zauważył w encyklice Evangelium vitae, prawo do życia jest najbardziej podstawowym, a zarazem fundamentalnym prawem, przysługującym każdej ludzkiej istocie - nie z racji szczególnych zasług czy zdolności, a z samego faktu bycia człowiekiem. $\mathrm{Z}$ tego też powodu ma ona całkowicie uzasadnione prawo oczekiwać absolutnego poszanowania tego najcenniejszego dobra ${ }^{7}$. Szczególną wartość życia ludzkiego wywodził ojciec święty z tajemnicy nadprzyrodzonego powołania przez Boga, który pozostawiając człowiekowi obietnicę życia wiecznego, nałożył nań obowiązek troski oraz doskonalenia w miłości doczesnej egzystencji.

Analogicznie Jan Paweł II pojmował sprawę narodu. Prawo do istnienia uważał za pierwsze i najważniejsze spośród wszystkich przysługujących mu przywilejów, o czym można się przekonać spoglądając chociażby na przybierające na sile napięcia etniczne - powodowane niczym innym, jak walką poszczególnych wspólnot o własny, niezależny od nikogo byt. Kwestię tę papież poruszył na forum Zgromadzenia Ogólnego ONZ, przedstawiając jego członkom dogłębną analizę geopolityczną świata, który dopiero co wyszedł z doświadczenia zimnej wojny. Pomimo iż jego słowa odnosiły się do konkretnej, minionej już sytuacji geopolitycznej, dziś rozbrzmiewają niczym przepowiednia, zaskakując swą aktualnością:

obserwujemy gwałtowne odradzanie się partykularyzmów etniczno-kulturowych, jak gdyby pod wpływem przemożnej potrzeby podkreślenia swojej tożsamości, przetrwania, stworzenia przeciwwagi dla tendencji niwelującej wszelkie różnice. Jest to zjawisko, którego nie wolno lekceważyć ani traktować jako zwykły relikt przeszłości;

5 A. Laun, Jan Pawet II - Papież życia odpowiedzialnego rodzicielstwa, „Ethos” (2000) nr 3 (51), s. 361.

${ }^{6}$ Jan Paweł II, enc. Evangelium vitae (O wartości i nienaruszalności ludzkiego życia), n. 42, Stolica Apostolska, https://w2.vatican.va/content/john-paul-ii/pl/encyclicals/documents/hf_jpii_enc_25031995_evangelium-vitae.html (10.09.2017).

7 Por. Jan Paweł II, enc. Evangelium vitae. 
fakt ten należy raczej wyjaśnić i uczynić przedmiotem pogłębionej refleksji antropologicznej i etyczno-prawnej.

O ile jednak Jan Paweł II za istotny uważał byt fizyczny narodu - pojmowany przede wszystkim w aspekcie troski o byt biologiczny - o tyle równie ważna, o ile nie ważniejsza, była dlań suwerenność realizująca się dzięki kulturze. Poparcie dla takich poglądów najpełniej odzwierciedla przykład jego życia. Przebywając już w Stolicy Piotrowej, z dala od ojczyzny i rodzinnych korzeni, Karol Wojtyła niejednokrotnie i zawsze $\mathrm{z}$ dumą podkreślał swoją tożsamość, czemu dał wyraz chociażby w siedzibie UNESCO, przyznając:

jestem synem narodu, który przetrwał najstraszliwsze doświadczenia dziejów, który wielokrotnie był przez sąsiadów skazywany na śmierć - a on pozostał przy życiu i pozostał sobą. Zachował własną tożsamość i zachował pośród rozbiorów i okupacji własną suwerenność jako naród - nie w oparciu o jakiekolwiek inne środki fizycznej potęgi, ale tylko w oparciu o własną kulturę, która okazała się w tym wypadku potęgą większą od tamtych potęg9.

Będąc zagorzałym obrońcą życia i prawa narodów do istnienia, nie mógł Jan Paweł II pozostać obojętny wobec problemów godzących w ich podstawy. Jako pierwszy dostrzegł zagrożenia, jakie roztacza cywilizacja śmierci posługująca się coraz to bardziej zaawansowanymi metodami, dążącymi do upokorzenia ludzkiego życia. Korzeni przemocy skierowanej przez człowieka wobec bliźniego ojciec święty dopatrywał się już na kartach Pisma Świętego. W encyklice Evangelium vitae przywołał historię Kaina i Abla, upatrując w niej genezy buntu, który dał początek bratobójczym walkom, tak nasilającym się we współczesnym świecie. Jan Paweł II przekonuje, że pytanie Stwórcy: „Cóżeś uczynił?”, skierowanie do zazdrosnego brata, nie zamyka się w biblijnej historii. Poprzez nie Bóg zwraca się także do sumienia współczesnego człowieka, aby zastanowił się nad ogromem spustoszeń wyrządzonych przez współczesne formy zamachów na ludzkie życie. Przywołuje tragedię XX wieku i pyta: cóżeś zrobił, człowiecze nowoczesnych technologii, z tysiącami ludzkich istnień, bestialsko odartych z godności w imię chorych ideologii? Cóżeś zrobił z obywatelami współczesnego świata, odrzucającymi drogę

8 Jan Paweł II, Od praw człowieka do praw narodów, przemówienie do członków Zgromadzenia Ogólnego ONZ, 5.10.1995, „Teologia Polityczna”, http://www.teologiapoli tyczna.pl/jan-pawel-ii-od-praw-czlowieka-do-praw-narodow (5.09.2017).

9 Jan Paweł II, Przemówienie wygłoszone w siedzibie UNESCO, 2.06.1980, Centrum Myśli Jana Pawła II, s. 14, http://www.centrumjp2.pl/wp-content/uploads/2015/01/PRZYSZ\% C5\%81O\%C5\%9A\%C4\%86-CZ\%C5\%81OWIEKA-ZALE\%C5\%BBY-OD-KULTURY-JanPawe\%C5\%82-II-.pdf (12.09.2017). 
porozumienia na rzecz bratobójczej wojny? Z ofiarami katów, cierpiącymi okrutne prześladowania tylko $\mathrm{z}$ racji urodzenia $\mathrm{w}$ nieodpowiednim miejscu, $\mathrm{w}$ innym kolorze skóry, o odmiennym wyznaniu, poglądach politycznych? Cóżeś zrobił $\mathrm{z}$ tysiącami ludzkich istnień, tych najbardziej bezbronnych i tak bardzo niechcianych, że nie zdążyły poznać świata innego niż tego pod sercem matki? Z dziećmi, które - głodne i zaniedbane - nie rozumieją, dlaczego znów nie będą miały czym zaspokoić skurczów żołądka domagającego się normalnego posiłku...

\section{Muhammad wycenia życie}

Muhammad - starszy brat Sary - pokazuje dziennikarzowi poprzedni dom, a w nim swój pokój. Miejsce, gdzie przyszedł na świat i spędził większość życia. Ukrywał w nim dziecięce sekrety, zanosił smutki, ale i szczęśliwe chwile. Miejsce, z którym łączył go głęboki sentyment, z którego posiada najpiękniejsze wspomnienia. Dziś, patrząc na to pomieszczenie, trudno uwierzyć, że mogło się komuś podobać. Zalegające wszędzie gruzy sprawiają wrażenie, jakby były tam od zawsze. W podobnym stanie pogrążona jest znaczna część Aleppo i wiele miast Syrii. Muhammad udaje dzielnego chłopaka - ma już przecież czternaście lat i trzy młodsze siostry. Musi być dorosły jak tata, nie może okazać słabości. Tylko czasami, kiedy nikt nie patrzy, pozwala sobie na chwilę być sobą i wyznaje: „pękło mi serce. W nocy płaczę i mówię sobie - chciałbym, żeby rewolucja była tylko snem. Czy to jest życie? Nie. Życie stało się tanie, kosztuje tylko dolara. Nie mam w sobie już żadnych uczuć" 10 .

Według danych opublikowanych na stronie UNICEF-u odnośnie do 2017 roku około 7,5 mln dzieci na świecie umiera z głodu ${ }^{11}$. Raport Organizacji Narodów Zjednoczonych ds. Wyżywienia i Rolnictwa (FAO) podaje z kolei, iż w 2016 roku na głód lub ciężkie niedożywienie cierpiało blisko $108 \mathrm{mln}$ osób, przy czym ich liczba w stosunku do roku poprzedniego wzrosła o $28 \mathrm{mln}^{12}$. Zatrważającą skalę tego zjawiska zdawał się doskonale dostrzegać Jan Paweł II, podnosząc prawo do wyżywienia do rangi podstawowych - obok życia - praw przysługujących każdemu człowiekowi. Wyraz trosce o losy najuboższych dał niejednokrotnie przy okazji licznych podróży po świecie oraz wystąpień na forum wielu organizacji. Co warte

10 Syria. Dzieci wojny, dz. cyt.

11 Por. UNICEF: 7,5 mln dzieci na świecie umiera z głodu, UNICEF Polska, https://www. unicef.pl/Centrum-prasowe/Informacje-prasowe/UNICEF-7-5-mln-dzieci-na-swiecie-umieraz-glodu (15.09.2017).

12 Por. 108 mln osób cierpiało głód lub ciężkie niedożywienie. Więcej niż rok wcześniej, TVN24, http://www.tvn24.pl/wiadomosci-ze-swiata,2/fao-108-mln-osob-cierpialo-glod-lubciezkie-niedozywienie-w-2016-r,728481.html (15.09.2017). 
podkreślenia, kwestię głodu na świecie papież Polak postrzegał w znacznie szerszej perspektywie, wiążąc ją nie tylko z problemem konkretnego kraju, ale z całą wspólnotą międzynarodową. Jak możemy bowiem przeczytać w jego przemówieniu do uczestników FAO z 2003 roku:

jest oczywiste, że ze względu na ścisłą zależność między głodem a pokojem, decyzje oraz strategie gospodarcze i polityczne muszą być w coraz większej mierze podyktowane dążeniem do globalnej solidarności oraz poszanowaniem fundamentalnych praw człowieka, w tym prawa do należytego wyżywienia. Decyzje przynoszące korzyść nielicznej garstce szczęśliwców, a nie uwzględniające cierpień licznych grup rodziny ludzkiej, podejmowane w imię samego tylko pragmatyzmu, dalekiego od obiektywnych wymogów prawa moralnego, są pogwałceniem godności człowieka ${ }^{13}$.

Z kolei w orędziu na Światowy Dzień Pokoju z tego samego roku wyraził przekonanie, iż ubóstwo, nędza, niesprawiedliwości społeczne - często usankcjonowane prawem - stanowią poważną przeszkodę dla harmonijnego rozwoju całej wspólnoty światowej ${ }^{14}$.

W obu tych wypowiedziach Jan Paweł II zwrócił uwagę na bardzo istotny problem - nierównego podziału dóbr w skali globalnej. W encyklice Dives in misericordia szczegółowo nakreślił obraz współczesnego świata, zbudowanego na ogromnych nierównościach. Świata, w którym obok zasobnych społeczeństw, ludzi żyjących w dostatku i hołdujących nadmiernemu konsumpcjonizmowi, nie brak jednostek, które nie mają niczego. „Nie brak małych dzieci, które umierają z głodu na oczach swoich matek. Nie brak w różnych częściach świata, w różnych systemach społeczno-ekonomicznych, całych obszarów nędzy, upośledzenia, niedorozwoju. Ten fakt jest powszechnie znany"15. A pomimo tego działania zmierzające do przeciwdziałania temu zjawisku wciąż są spychane na margines wielkich polityk przywódców, opierających swoje postulaty na fasadach równości. Jan Paweł II nauczał przy tym, że owo „zrównanie” pomiędzy ludźmi dopiero dopełnione miłością i miłosierdziem może zapewnić człowiekowi przysługującą mu godność ${ }^{16}$. Podźwignąć go fizycznie $z$ warunków skrajnej nędzy może natomiast

13 Jan Paweł II, Głód zagrożeniem dla pokoju, przemówienie podczas spotkania z uczestnikami 32 konferencji FAO, 5.12.2003, n. 2, Fundacja Opoka, http://www.opoka.org. pl/biblioteka/W/WP/jan_pawel_ii/przemowienia/fao_05122003.html (5.09.2017).

14 Por. Jan Paweł II, Jeśli pragniesz pokoju, wyjdź naprzeciw ubogim, orędzie Jana Pawła II na XXVI Światowy Dzień Pokoju, n. 1, Fundacja Opoka, http://www.opoka.org.pl/biblioteka/W/ WP/jan_pawel_ii/przemowienia/pokoj1993_08121992.html, (5.09.2017).

15 Jan Paweł II, enc. Dives in Misericordia (O Bożym Miłosierdziu), Kraków 2010, n. 11.

16 Por. Jan Paweł II, enc. Dives in Misericordia.. 
postęp naukowo-technologiczny - potężne narzędzie, które mając możliwości wspomożenia ludzkiego życia, kierowane jest często przeciwko niemu...

\section{Helen zastępuje szkołę}

Helen - starsza siostra Sary - miała przywilej uczęszczać do szkoły, zanim Syria pogrążyła się w wojnie domowej. Tylko dzięki szczęściu urodzenia się kilka lat wcześniej zyskała możliwość nabycia umiejętności czytania i pisania. W początkowym etapie edukacji. Kiedy bowiem wybuchła rewolucja, a szkoła jeszcze funkcjonowała, dziewczynka nie miała w niej łatwego życia. Była w końcu córką dowódcy Syryjczyków domagających się obalenia reżimu. Stała się więc jego czołowym wrogiem. Helen wspomina, że gdy tylko nauczyciele dowiedzieli się o poglądach jej rodziny, stali się dla niej wyjątkowo surowi. „Gdy wychodziłam z klasy, dyrektorka mnie biła. Kiedy schodziłam po schodach, bałam się, że nauczyciele mnie porwą albo zabiją, bałam się, że zaciągną mnie do piwnicy. Umierałam ze strachu"17. Pragnęła oszczędzić tego rodzeństwu, które jednak na podobne szykany nie zostało narażone - szkoły zmieniono w bazy wojskowe. Dlatego nauczycielką została Helen. To ona nauczyła Sarę i jej siostrę umiejętności pisania. Jak wyznała: „pragnę, aby moje rodzeństwo było szczęśliwe, żeby cieszyło się dzieciństwem”18. Helen jest niewiele starsza od pięcioletniej Sary.

Kwestię kultury Jan Paweł II wyniósł w swoim nauczaniu do rangi jednego z podstawowych uprawnień, przysługujących tak człowiekowi, jak i narodom. Zdaniem ojca świętego to właśnie dziedzictwo kulturowe dopełnia człowieczeństwo, jest efektem ludzkiej godności oraz w zasadniczy sposób ją warunkuje:

Człowiek żyje prawdziwie ludzkim życiem dzięki kulturze. Jego życie jest kulturą również i w tym znaczeniu, że poprzez nią człowiek odznacza się i odróżnia od całej reszty istnień wchodzących w skład widzialnego świata: człowiek nie może obejść się bez kultury ${ }^{19}$.

Nie może także bez jej udziału stworzyć prawdziwych, trwałych relacji z bliźnim - to ona bowiem stanowi o międzyludzkim i społecznym charakterze ludzkiego bytowania. Co ojciec święty rozumie przez tak pojętą kulturę? W najbardziej podstawowym znaczeniu to właściwy sposób istnienia człowieka, jego prawo do tego, aby bardziej „być”, prawo do miłości, ze względu na szczególną godność, jaką

17 Syria. Dzieci wojny, dz. cyt.

18 Syria. Dzieci wojny, dz. cyt.

19 Jan Paweł II, Przemówienie wygłoszone w siedzibie UNESCO, 2.06.1980, dz. cyt., n. 6. 
posiada. Właściwie pojęta kultura wymaga, aby do końca i integralnie postrzegać osobę ludzką jako szczególną wartość, podmiot związany z transcendencją, mało tego - głosi ona zawsze pochwałę życia, afirmację człowieka - nie z jakichkolwiek racji, ale ze względu na niego samego i jego godność ${ }^{20}$.

Kultura jest wychowawcą nie tylko ku temu, żeby „bardziej być”, ale co ważne „bardziej być” we wspólnocie, która ma dłuższą historię niż człowiek i rodzina. Naród istnieje z kultury i dla kultury ${ }^{21}$. Na potwierdzenie tych słów Jan Paweł II wielokrotnie przywoływał historię własnej ojczyzny, która zniewolona i wykreślona z map świata fizycznie straciła prawo istnienia, dzięki kulturze jednak odrodziła się i odzyskała suwerenność, bowiem „każdy naród żyje dziełami swojej kultury"22, to także dzięki niej odróżnia się od innych wspólnot. Z nią natomiast ściśle powiązana jest swoboda wyznania, którą w dużej mierze warunkuje. Jan Paweł II przekonywał, iż to właśnie od momentu chrztu Polska ugruntowała się jako naród, przy czym sakrament ten postrzegał nie tylko jako akt chrześcijańskiej inicjacji przyjęty przez Mieszka, ale wydarzenie, które odegrało fundamentalną rolę w ukształtowaniu się jej chrześcijańskiej tożsamości. Tak rozumując, kompletnej definicji kultury dopatrywał się ojciec święty już w Księdze Rodzaju, w słowach Stwórcy: „Czyńcie sobie ziemię poddaną”, to znaczy odkrywajcie prawdę o własnym człowieczeństwie. Ta dwoista prawda - o świecie i o sobie samym, jest najważniejszą misją zadaną ludziom kształtującym świat widzialny, a wraz z tym własną kulturę ${ }^{23}$. Jak bowiem dowodził, posługując się łacińską paremią: „Genus humanum arte et ratione vivit" ${ }^{24}$ - człowiek jest sobą przez prawdę, staje się sobą przez coraz pełniejsze jej poznanie.

Ze zgłębianiem prawdy ściśle powiązany jest rozwój nauki. Jan Paweł II odnosił się do niej z wielkim entuzjazmem, podkreślając niejednokrotnie jej związki z posłannictwem Kościoła, którego korzenie można odnaleźć już w dobie średniowiecznych uniwersytetów. Jednocześnie jednak ojciec święty dostrzegał poważne niebezpieczeństwo związane z wykorzystywaniem jej wytworów wbrew nakazom etyki, do celów, które nie tylko niewiele mają wspólnego z wymogami nauki, co wręcz wykorzystywane są do zagłady o nieznanych dotąd rozmiarach. Niebezpieczeństwo polegające na tym, iż zamiast pozostawać w służbie ludzkiego życia, kultura wykorzystywana jest przeciwko niemu. W tym kontekście szczególną uwagę Jan Paweł II zwracał na ryzyko użycia broni nuklearnej, która nie tylko może obrócić w niwecz wypracowane przez wieki osiągnięcia cywilizacji, lecz do-

20 Por. Jan Paweł II, Przemówienie wygłoszone w siedzibie UNESCO, 2.06.1980, dz. cyt.

${ }_{21}$ Por. Jan Paweł II, Pamięć i tożsamość. Rozmowy na przełomie tysiącleci, parafia Wilanów, s. 65, http://www.parafiawilanow.pl/biblioteka/jp2_pamiec_i_tozsamosc.pdf (15.09.2017).

22 Jan Paweł II, Pamięć i tożsamość..., dz. cyt., s. 63.

23 Por. Jan Paweł II, Pamięć i tożsamość..., dz. cyt., s. 61.

${ }^{24}$ Jan Paweł II, Przemówienie wygłoszone w siedzibie UNESCO, 2.06.1980, dz. cyt., n. 6. 
prowadzić do zagłady ludzkości. Z wielkim niepokojem obserwował fakt, iż coraz więcej państw nabywa oraz powiększa swoje arsenały nuklearne, a także apelował do sumień współczesnych ludzi, by nie pozostawali obojętnymi na tragedie, będące wynikiem użycia nauki do zabijania. Coraz bardziej powszedniejące dla publicznej opinii dramaty ludzi, którym wykorzystana w zbrodniczy sposób nauka odebrała dobytek, najbliższych, życie...

\section{Abude demonstruje dla wolności}

W Bustan al-Kaser, głównym bazarze rebelianckiego Aleppo, co tydzień dochodzi do demonstracji. Od jakiegoś czasu ich twarzą jest dwunastoletni Abude. $\mathrm{Na}$ początku organizował protesty w szkole, kiedy jednak go wyrzucili, przeszedł do prawdziwej opozycji. Dziś śpiewa rebelianckie piosenki podczas ulicznych manifestacji. Na początku towarzyszył mu kolega, ale zabiła go rakieta - dlatego obecnie śpiewa z nim Nasma. Jak sam mówi: „takie demonstracje stały się naszą profesją, jesteśmy od nich uzależnieni. Jeśli nie demonstrujemy w każdy piątek, nie mamy nic innego do roboty ${ }^{25}$. Kiedy ojciec pewnego razu zabronił chłopcu wyjść z domu, ten płakał przez kilka godzin. Będąc aktywistą, Abude naraża się na duże ryzyko, dlatego rebelianci zadbali o bezpieczeństwo chłopca: „nosimy noże dla obrony. Dali mi pistolet, ale nie umiem się nim posługiwać"26.

Wolność jest istotnym prawem, przysługującym ludziom i tworzonym przezeń narodom. „Istota wolności tkwi we wnętrzu człowieka, należy do natury osoby ludzkiej i jest jej znakiem rozpoznawczym. Wolność osoby ma rzeczywiście swój fundament w transcendentnej godności człowieka: w godności danej mu przez Boga, jego Stwórcę"27. Będąc stworzonym na Jego obraz i podobieństwo, człowiek został nierozerwalnie związany z wolnością, której nie jest w stanie go pozbawić żaden przymus ani siła fizyczna. W naturę ludzką wpisana została nie tylko sama jej wartość, ale i bogate pragnienie. Jan Paweł II najpełniej obrazuje to, przywołując przykład bezkrwawych rewolucji 1989 roku. Posługując się nimi, pokazuje, że poszukiwanie wolności jest niepowstrzymanym dążeniem, gdyż jej kształt wytyczony jest nie granicami państwowymi, a zakorzeniony w godności człowieka, w nieocenionej wartości osoby ludzkiej ${ }^{28}$. Sytuacja współczesnego świata dowodzi najpełniej prawdziwości tych słów. Gotowość poświęcenia własnego życia dla

${ }_{25}$ Syria. Dzieci wojny, dz. cyt.

26 Syria. Dzieci wojny, dz. cyt..

27 Jan Paweł II, Chcesz służyć sprawie pokoju - szanuj wolność, orędzie Jana Pawła II na XIV Światowy Dzień Pokoju, „Niedziela”, n. 5, http://niedziela.pl/artykul/2274/Oredzie-naXIV-Swiatowy-Dzien-Pokoju---1 (5.09.2017).

28 Por. Jan Paweł II, Od praw człowieka..., dz. cyt. 
utrzymania bądź odzyskania wolności podkreśla jej uniwersalną wartość oraz doniosłe miejsce, jakie zajmuje na liście priorytetów człowieka wszystkich czasów. Życie w jej warunkach stanowi zdaniem ojca świętego ogromną szansę dla rozwoju duchowego człowieka oraz moralnego ożywienia narodów. Aby jednak wolność była w pełni realizowana, potrzebny jest klimat zaufania w stosunkach międzynarodowych. Jak bowiem przekonuje papież Polak, nie będzie jej tam, gdzie dążenia narodów uwarunkowane będą uciskiem oraz wzajemną obawą, gdzie stosunki między nimi opierać się będą na prawie silniejszego, imperializmie wojskowym lub politycznym, gdzie mniejsze i słabsze narody dla zapewnienia sobie przetrwania będą zmuszone zrzec się swojej suwerenności na rzecz silniejszych. Próżno jej wreszcie szukać także tam, gdzie narody uprzywilejowane jako środka dominacji używają nie tylko siły militarnej, ale i potęgi gospodarki, stanowiącej istotną determinantę prawdziwej suwerenności ${ }^{29}$. Dopiero pozbawiona powyższych niebezpieczeństw wolność może stać się podstawą prawdziwego i trwałego pokoju, rozumianego nie tylko jako brak działań militarnych, ale i nieobecność anarchii i represyjnych reżimów, nieobecność bezrobocia, wyzysku pracowniczego oraz niegodnych warunków pracy, medialnej manipulacji, a także jako swobodny udział wszystkich obywateli w podejmowaniu decyzji ${ }^{30}$. Sytuacja, której zabrakło protestującym Syryjczykom.

Jan Paweł II poruszył zagadnienie wolności niezwykle dogłębnie, zwracając uwagę na dwie istotne kwestie. Po pierwsze zauważył, iż wolność „nie jest jedynie prawem, którego żąda się dla siebie; jest ona również powinnością, którą podejmuje się wobec drugich"31. To szczególny dar, z którym wiąże się jednak zadanie dzielenia się z bliźnimi, odpowiedzialność, aby zabiegając o własną wolność, nie naruszać granic czyjejś. Karol Wojtyła podkreślał niejednokrotnie, iż jest ona wartością, która nie jest podarowana na zawsze: „wolność stale trzeba zdobywać, nie można jej tylko posiadać. Przychodzi jako dar, utrzymuje się jako zmaganie"32. Potwierdzenie tych słów znajdywał w bolesnych doświadczeniach własnego narodu, w trudzie, jaki sam włożył w walkę o jej odzyskanie. Kolejną kwestią, przed którą przestrzegał ojciec święty, są pozory wolności, zafałszowane formy, jakie próbuje jej nadać współczesny świat. Nauczając iż ta prawdziwa, podarowana od Boga nie może prowadzić w innym kierunku, jak do poznania prawdy, przekonywał, iż współcześnie często mylnie nazywa się wolnością coraz bardziej nienasycone poszukiwanie dóbr (najczęściej kosztem krajów najuboższych), pozbawione nie tylko nakazów sprawiedliwości, ale i miłości społecznej. Nie ma także wolności w spo-

\footnotetext{
29 Por. Jan Paweł II, Chcesz służyć sprawie pokoju..., dz. cyt.

30 Por. Jan Paweł II, Chcesz służyć sprawie pokoju..., dz. cyt.

31 Jan Paweł II, Chcesz stużyć sprawie pokoju..., dz. cyt.

32 Jan Paweł II, Pamięć i tożsamość, dz. cyt., s. 57.
} 
łeczeństwie permisywnym, traktującym ją jako zezwolenie na jakikolwiek wybór, firmujący powszechną amoralność, pogwałcenie zasad etyki w życiu społecznym. To mylne złudzenie często prowadzi współczesnego człowieka do przekonania o możliwości decydowania o ludzkim życiu, co swój wyraz znajduje chociażby w zabójstwie dzieci nienarodzonych czy samym akceptowaniu tego procederu ${ }^{33}$. W takiej sytuacji można mówić o wypaczeniu wolności, które w konsekwencji prowadzi do zniewolenia, anarchii i wojny. „Wolności”, za którą cenę płacą niewinni...

\section{Sara wciąż marzy}

Opisane powyżej uprawnienia, przysługujące tak pojedynczym osobom, jak i tworzonym przezeń narodom, są jedynie najważniejszymi z postulowanych przez Jana Pawła II. Ich katalog jest tak bogaty, jak wielkie było jego zainteresowanie sytuacją światową oraz zatroskanie losem najsłabszych, uciśnionych, często tych praw pozbawianych. Walkę o poprawę ich losu, bardzo często walkę trudną i niezgodną z poprawnością współczesnego świata, kontynuował do ostatnich dni, zarówno podnosząc apele do sumienia współczesnego świata, jak i fizycznie, odwiedzając uciśnionych i zapalając ich serca do walki o własną godność. I nawet jeżeli nie udało mu się zaprowadzić trwałego pokoju na świecie, jeżeli kliniki aborcyjne wciąż zyskują nowych interesantów, ulice niejednego miasta przepełnione są bezdomnymi oraz ubogimi, których ostatnim uczuciem przed śmiercią jest uczucie głodu, a na barykadach coraz to nowszych konfliktów zbrojnych krew przelewają niewinni ludzie, broniący jedynie swoich praw, to jednak dla wielu z nich zrobił więcej, niż mógłby uczynić w materialny sposób. Pomógł ocalić im godność i duszę - coś, czego nikt żadną siłą nie jest w stanie człowiekowi odebrać. A także wlał w ich serca najcenniejszy dar - nadzieję. Pomimo wielu strasznych doświadczeń, codziennego obcowania ze śmiercią oraz wszechobecnym złem, Sara ma jeszcze swój świat, w którym jest pięknie: „czasami jeżdżę na koniu, biegam, śmieję się. Ulice są czyste, wszędzie kwitną kwiaty, ludzie zbierają się i śpiewają" ${ }^{34}$. Dziś jest to jeszcze świat snów i marzeń. Dziś też Jan Paweł II nie może jej pomóc fizycznie. Nie może - jak miał to w zwyczaju - odwiedzić pogrążonych w konfliktach krajów i tchnąć w nie nadzieję oraz wolę walki - nie karabinami, a miłością - o godność osoby ludzkiej. Zostawił jednak po sobie testament, wskazówki, jak postępować, by nie dokonać samozagłady - tej fizycznej, jak i przede wszystkim moralnej. Czy jesteśmy gotowi stanąć do walki najważniejszej - o samych siebie?

33 Por. Jan Paweł II, Chcesz służý sprawie pokoju..., dz. cyt.

34 Syria. Dzieci wojny, dz. cyt. 


\section{Abstract}

\section{Human rights, the rights of nations - at all costs or despite everything?}

The topic of this thesis titled Human rights, the rights of nations - at all costs or despite everything? is the issue of human rights in teaching John Paul II. The primary objective was to show that the question of the dignity of the human person and his freedoms played an important role in the pontificate of the Polish pope. The author proves this by referring to chosen speeches, homilies and encyclicals of the Holy Father. Besides this, the author gives in her essay voice to Syrian children form the documentary Children of Syria; directed by Marcel Mettelsiefen and through this shows nature of war through the eyes of children. The conclusion is that the teaching of John Paul II has a timeless character and universal application in the modern world. 